\title{
PAPEL DA EMBRAPA NO DESENVOLVIMENTO DO AGRONEGÓCIO
}

\author{
Renner Marra ${ }^{1}$ \\ Geraldo da Silva e Souza ${ }^{2}$ \\ Eliseu Roberto de Andrade Alves ${ }^{3}$
}

RESUMO: Para descrever as contribuições da Embrapa, procurou-se caracterizar o contexto em que a Embrapa foi criada, a fim de mostrar que sua criação foi decisão consciente do governo federal para enfrentar problemas graves de abastecimento, expandir e diversificar as exportações. Ou seja, a Embrapa foi estabelecida para resolver problemas específicos, com um mandato específico de produzir tecnologias que os agricultores pudessem usar.O texto ressalta a importância das universidades, dos institutos de pesquisa estaduais e da pesquisa internacional. O Brasil dispõe hoje de um complexo sofisticado de ciências agrárias que produz tecnologias e é abastecido por problemas de nossa agricultura e também da dos países subdesenvolvidos, principalmente da África. Um dos pilares do agronegócio é o crescimento da produtividade da agricultura, crescimento este reconhecido como vitória das ciências agrárias, da engenhosidade de nossos agricultores, da estabilidade econômica e das instituições que tem como responsabilidade específica desenvolver a agricultura. $\mathrm{O}$ texto ressalta o sucesso do agronegócio e a necessidade de encontrar solução para os milhões de excluídos da modernização. É feita uma resenha de nossa política agrícola, na qual a reforma agrária é abordada.

Palavras- chave: modernização; tecnologia; agrarianismo; agronegócio; produtividade.

1 Economista, Empresa Brasileira de Pesquisa Agropecuária - Embrapa, Endereço: Embrapa Sede, Parque Estação Biológica - PqEB s/nº, Brasília, DF - Brasil - CEP 70770-901. Fone: (61) 3448-4123.

E-mail: renner.marra@embrapa.br

$2 \mathrm{PhD}$ em Estatística, Pesquisador da Embrapa. Endereço: Secretaria de Gestão Estratégica, PqEB Av. W3 Norte (Final) Ed. Sede, Brasília, DF, 70770-901. Telefone: (61)3348-4194. E-mail: Geraldo.Souza@embrapa.br

$3 \mathrm{PhD}$, assessor do Diretor Presidente e Pesquisador, Empresa Brasileira de Pesquisa Agropecuária, PqEB Av. W3 Norte (Final) Ed. Sede, Brasília, DF, 70770-901.Telefone: (61)3448-4202. E-mail: Eliseu.Alves@embrapa. br 


\begin{abstract}
To describe Embrapa role in the development of the agribusiness it was important to characterize the economic environment that prevailed in the sixties and beginning of the seventies to show that the creation and development of Embrapa was a conscious decision of the federal government to bolster agricultural production and exports to solve food supply deficiencies and balance of payment problems. The mandate of Embrapa was very specific and clear: to generate technology for the adoption of the farmers. The paper stresses the importance of the universities, state research and the connections with international advanced research centers. Brazil developed an important agricultural research complex to deal with problem of tropical environment. This complex handles technologies to the farmers and is fed by their problems. Presently is also working with farmer problems of Africa, Asia and Latin America countries. The growth of productivity at the farmer level explains much of the success of the agribusiness, and it is one of the greatest successes of agrarian sciences, of farmer ingenuity, macroeconomic stability, and of the institutions in charge of the development of agriculture. Side by side with great success of the agribusiness there are millions of small producers left at the margin of modern agriculture. To solve their problem is one of the most important challenges of Brazilian society. The text also reviews Brazilian agricultural and agrarian reform policies.
\end{abstract}

Keywords: modern agriculture; agrarianism, technology; agribusiness; productivity.

\title{
1. Preliminares
}

Embora se ressalte a Embrapa, é importante salientar que ela é parte de um grande complexo de ciência e tecnologia que inclui os governos federal, estaduais e municipais, a iniciativa particular, órgãos financiadores brasileiros e externos, instituições de pesquisa do mundo desenvolvido e em desenvolvimento. Sendo assim, do ponto de vista de ciência e tecnologia, é este poderoso complexo que abastece o agronegócio com tecnologia e é abastecido por ele com problemas a estudar e por questionamentos. Isto não nega as particularidades de cada instituição, e ao focalizá-las, corre-se o risco de injustiças, das quais quero desde já me penitenciar.

Outro ponto a salientar é que o agronegócio inclui a agricultura familiar. Mantém-se, contudo, tanto do ponto vista de exposição como de política 
pública, a divisão. Do ponto de vista de política pública, visando isolar o grupo de beneficiários, a divisão se impõe.

O Brasil aumentou substancialmente os investimentos em educação, em nível federal, estadual e municipal, a partir de 1970. Neste respeito, os estados das regiões Sul e Sudeste se adiantaram aos demais. O meio rural tem sido discriminado no que diz respeito às escolas rurais. Elas perdem em qualidade, quando comparadas com as urbanas, e nelas o investimento por aluno é muito menor. Como solução deste problema, os prefeitos preferem oferecer transportes para os estudantes do meio rural frequentarem escolas urbanas. O que favorece o êxodo rural, pois as escolas só os preparam para o destino de vida mais provável, que é viver nas cidades.

Os investimentos em educação tiveram sucesso em criar o capital humano necessário para desenvolver o agronegócio que se assenta em 11,4\% de todos os estabelecimentos que informaram produção e a exploração da terra em 2006. Pelo censo agropecuário de 2006: cerca de quinhentos mil em 4,4 milhões. $\mathrm{E}$ a falta de investimentos em educação no meio rural tem muito a ver com a concentração da produção, em tão poucos estabelecimentos, e com a marginalização de 3,9 milhões deles.

A política de industrialização data dos anos 30 e dominou a política econômica no período 1950-85. Como consequência dela, o Brasil se industrializou e urbanizou. Nas décadas de 50 e 60, a agricultura contribuiu com vultosos recursos para seu financiamento, e houve grandes transferências de recursos do meio rural para as cidades, conforme documentado por vários estudos como Barros (2010) e Brandão (2013)4. Nas duas décadas citadas, preferiu-se que a agricultura expandisse a produção via incorporação de terra à produção, com a tecnologia tradicional. Na década de 70, a política econômica, no âmbito da de industrialização, passou enfatizar a modernização da agricultura, e assim tem permanecido. Com a urbanização, a liderança rural perdeu muito do seu poder para o complexo urbano-industrial. Ainda o complexo urbano-

4 Brandão procura chamar atenção para subsídio financeiro ao crédito. Numa economia aberta com controle de juros pelo governo, a taxa de juros brasileira não é boa métrica para medir subsídios. 
industrial assumiu a liderança da agricultura moderna, e o agronegócio é o seu filho mais ilustre.

\section{Introdução}

Num curto espaço de tempo, o Brasil construiu poderoso agronegócio que tem abastecido sua população a preços estáveis, e por um longo período a preços declinantes, pagou grande parte de sua dívida externa e ajudou acumular montante respeitável de reservas externas. Ainda emprega, no seu conjunto urbano-rural, expressiva parcela da população ativa brasileira.

Salienta-se que a política agrícola perseguiu este objetivo, usando de vários instrumentos para alcançá-lo, e os sinais dados por ela foram entendidos e transformados em decisões pelo setor privado, sejam eles agricultores, agroindústrias e exportadores. Assim, o desenvolvimento do agronegócio, como a industrialização do país, foram opções do governo que convenceu a sociedade de suas vantagens. A decisão de industrializar o Brasil firmou pé no decorrer dos anos cinquenta. A de modernizar nossa agricultura retardou-se. Seu início, em nível de governo federal, é dos anos setenta. Ambas as decisões estão nas raízes do sucesso do agronegócio.

A industrialização, seguida da rápida urbanização, criou amplo mercado interno para a agricultura. A recente abertura comercial e o câmbio flutuante abriram as portas para o mercado externo, num período em que a demanda de alimentos cresce a taxas elevadas, principalmente nos países asiáticos. Deste modo, a demanda externa e a interna, num ambiente de relativa estabilidade econômica, criaram as condições para o desenvolvimento da agricultura moderna.

Ciência e tecnologia, extensão rural pública e particular, crédito rural, investimentos em estradas, portos e aeroportos, em irrigação, em agroindústria permitiram a oferta responder adequadamente aos sinais 
da demanda. Reconhece-se, assim, que tanto do lado da demanda como da oferta, políticas publicas tiveram papel importante. É óbvio, que sem a pronta reação do setor privado, o sucesso do agronegócio não teria ocorrido!

As ações do governo visaram estimular o crescimento da produção, no que foi muito bem sucedida. Com a redemocratização, em 1988, as questões de natureza redistributivas passaram a ser tratadas pelas políticas públicas, com maior intensidade. Reforma agrária, agricultura familiar, crédito específico para reforma agrária e agricultura familiar (PRONAF) e especialização da extensão rural na agricultura familiar, considerando-se também as ONGs, receberam vultosos investimentos do governo federal, e, em menor grau por estados e municípios.

Não obstante os esforços feitos, os dados do Censo Agropecuário de 2006 evidenciaram que $88,6 \%$ dos estabelecimentos recenseados somente produziram $13 \%$ da produção de 2006 . Equivalentemente, $11,4 \%$ de todos os estabelecimentos produziram $87 \%$ da produção daquele ano. Estamos, portanto, diante de enorme desafio, qual seja o de incluir a agricultura moderna os que ficaram à margem da modernização, (Alves, Souza, Rocha, Marra, 2013). Voltaremos ao tópico, com mais detalhes, mais adiante.

\section{Desenvolvimento da agricultura: três fases importantes}

Do ponto de vista de política agrícola, distinguimos três fases, a saber: expansão da fronteira agrícola com a agricultura extrativa, agronegócio, agronegócio mais agricultura familiar e reforma agrária. Uma fase não se exaure para começar a outra. É questão de dominância, apenas. Por exemplo, nos dias de hoje temos ainda as três fazes. Mas, a agricultura extrativa explica muito pouco do crescimento da produção. E as políticas públicas enfatizam ao mesmo tempo o agronegócio, a agricultura familiar e a reforma agrária. No entanto, no período de 1970 a 1988, a ênfase recaiu no agronegócio e, em menor escala, na agricultura familiar. 


\subsection{Expansão da fronteira agrícola com a agricultura extrativa, do descobrimento a 1965.}

Nesta fase - do descobrimento até 1965 , e ela não está totalmente ultrapassada, a agricultura fundamentou-se em terra, trabalho e em insumos produzidos no meio rural, e, por isto, quanto aos insumos, sem conexões com as cidades. Nesta agricultura, o crescimento da oferta corresponde à expansão da área explorada, a produtividade da terra permanece estagnada, e ela sempre caminhou à busca de terra fértil, e em matas. Este tipo de agricultura dominou a produção até a década de cinquenta, portanto num longo período, desde o descobrimento. De cinquenta em diante, começou a ceder lugar à baseada em insumos modernos. A tradicional ainda está presente em todo o território nacional e, ainda, domina a produção na região Norte. Atualmente, explica pequena parcela do crescimento da produção.

A construção de estradas, crédito para financiar a produção, as exportações e a conquista do mercado externo foram muito importantes para financiar o crescimento da produção. Quanto ao mercado externo, o domínio do café foi absoluto ${ }^{5}$. As culturas voltadas para o abastecimento interno eram especializadas neste segmento, sem pretensões de exportações. É claro que houve pequenas exceções, sendo o algodão uma delas. Em nível de governo federal, não houve preocupações com o aumento da produtividade da terra. São Paulo e Rio Grande do Sul fugiram à regra, com suas instituições de pesquisa e assistência técnica, mas sem impacto na produtividade, em nível nacional.

A agricultura extensiva, ou extrativa, era coerente com as políticas de industrialização vigentes nas décadas de cinquenta, sessenta e setenta, pois não competia em capital com a indústria. Por isto, naquele período como no passado, foram enfatizadas políticas compatíveis com a expansão da área dominada pela agricultura, como construção de estradas e portos, as exportações de café e a abertura do mercado de trabalho para a imigração.

5 Pelo café, a agricultura se ligou ao mercado externo e ficou somente neste produto. 
A visão de que uma agricultura extrativista era apropriada ao Brasil, comportou algumas exceções induzidas pelo exterior, e não como demanda interna. O imperador Dom Pedro II criou o Mapa em 1860. Teve muito ver com a criação da Escola de Agronomia Cruz das Almas, em 1859 que funcionou em 1876. A Escola de Agronomia Eliseu Maciel, em Pelotas, Rio Grande do Sul, é de 1883. O Instituto Agronômico de Campinas data de 1887, e ele teve enorme influência em toda a pesquisa agrícola brasileira, e é referência mundial. A Escola Superior de Agricultura Luiz de Queiroz foi fundada em 1901. A Escola Superior de Agricultura de Lavras data de 1908. A Escola Superior de Agricultura e Veterinária de Viçosa foi estabelecida em 1922, e passou a funcionar em 1927. Destacam-se ainda a criação de atividades de assistência técnica e fomento no Ministério da Agricultura, estados e em alguns municípios.

Não obstante a dominância da visão favorável à expansão da fronteira agrícola com a agricultura extrativista, em 1948, por influência de Nelson Rockfeller, a extensão rural, na visão americana, chegou a Minas Gerais e daí se expandiu para o Brasil. A hipótese que ensejou seu desenvolvimento em todo o território nacional afirmava existir nas gavetas dos pesquisadores brasileiros grande estoque de conhecimentos que não se difundia, porque o Brasil não contava com adequado serviço de extensão rural. Esta hipótese lastreou a criação da extensão rural em quase todo o território nacional. Em primeiro lugar, como iniciativa dos estados e depois, do governo federal: com o estabelecimento da Abcar, 1956 e do sistema Ater, 1974. O apoio do governo federal à extensão rural sinalizava mudança de atitude, em favor do incremento da produtividade da terra, quando ainda dominava a visão da agricultura extrativista.

A industrialização foi muito bem sucedida em convencer a opinião pública de seus méritos. Depois da redemocratização, em 1946, o último presidente eleito de raízes rurais foi Getúlio Vargas. Ele se elegeu em três de outubro de 1950. Mas, Getúlio foi, desde 1930, muito vinculado à industrialização do Brasil. O meio rural, o da política do café com leite, nunca mais voltou ao poder, preterido pelo eleitorado que preferiu candidatos comprometidos com a industrialização e com o meio urbano. 
Consolidada a urbanização, já com $85 \%$ da população residindo nas cidades, os campos não têm mais condições de eleger um presidente, com visão rural predominante. Contudo, considerando-se a expressão econômica do agronegócio, este tem peso na plataforma eleitoral dos candidatos com chances de vencerem as eleições. Mas, note-se ser o agronegócio expressão do complexo urbano industrial, com sua visão muito influenciada pela necessidade de exportar cada vez mais. $\mathrm{O}$ agronegócio é a expressão da marcante integração das cidades com os campos, integração que faz obsoleta a divisão urbano-rural, exceto por conveniência das contas nacionais. A agricultura do agronegócio é imensa linha de montagem que reúne conhecimentos oriundos da ciência brasileira e do exterior, das experiências e vivências dos agricultores, sendo que, pelo menos $60 \%$ dos insumos, são comprados da urbis e quase toda produção comercializada no Brasil e exterior. É verdade que existe o Brasil rural, ainda à margem desta integração, cultural muito expressivo, mas pouco importante, quanto ao volume da produção.

\subsection{Agronegócio, 1965 a 1988.}

No começo dos anos 60, percebeu-se que somente a expansão da fronteira agrícola não seria suficiente para atender às demandas de alimentos, seja ela de origem interna ou externa ao estabelecimento. Em 1965, se estabeleceu o crédito rural, fundamentado no financiamento de insumos modernos e da agroindústria, e se ampliou, a partir daquele ano, substancialmente os investimentos em extensão rural, sendo então dominante a visão de que existia nas gavetas dos pesquisadores suficiente estoque de conhecimento para tirar nossa agricultura de seu atraso milenar. No entanto, o crescimento da produtividade da terra não respondeu à política de credito e extensão rural. Algo teria que ser feito.

No período 1970-76, o preço da cesta básica teve crescimento anual de $6,52 \%$. Houve desabastecimento em São Paulo, Rio de Janeiro, Belo Horizonte e outras capitais, com longas filas para comprar comida e 
demonstrações inequívocas de insatisfação popular com a escassez de alimentos e também com os salários vigentes. Compreendeu-se ser falsa a hipótese da existência de amplo estoque de conhecimento, e ela foi rejeitada. E ainda que não houvesse outro caminho a não ser investir maciçamente em ciências agrárias. Essa compreensão passou a guiar as políticas do governo.

A Embrapa foi estabelecida em 26 de abril de 1973, com a incumbência de gerar a base de conhecimentos de que tanto a agricultura carecia, e tem sido prioritária, como política pública desde então. Na mesma linha, os cursos de pós-graduados em ciências agrárias foram expandidos em todo o território nacional. Deu-se enorme ênfase à pós-graduação no Brasil e no exterior, e também aos projetos de pesquisas em ciências agrárias das universidades e dos institutos de pesquisa, além da Embrapa.

Dentro da política de expandir o relacionamento com os centros de excelência em ciências agrárias, número expressivo de estudantes das universidades e da Embrapa foi fazer o doutorado nos Estados Unidos, Europa, Austrália, Canadá e Japão. A Embrapa criou, em cooperação com países, laboratórios virtuais (os labexes, sem base física pertencente à Embrapa) nos Estados Unidos, França, Inglaterra, Coreia e China. Os cientistas seniores são enviados, se juntam a cientistas dos países, para realizarem projetos de pesquisa de interesse comum. Também cientistas do exterior podem vir ao Brasil, com o mesmo propósito, (Agropolis, 2013).

Como políticas tradicionais, expandiu-se muito o crédito rural para agricultores e agroindústria, enfatizou-se ainda mais construção de estradas e se ampliaram os investimentos em extensão rural. Contudo, ciência e tecnologia passaram a ser a base da nossa política agrícola. Assim foi a conquista dos cerrados, da Amazônia e de outros biomas. Expandir a fronteira agrícola, mas sim com a agricultura moderna. A política agrícola soube, assim, conjugar a expansão da fronteira agrícola com a moderna agricultura. 
Investiu-se muito em rodovias, que ligaram os centros de produção aos mercados urbanos e aos portos e aeroportos, o que permitiu notável expansão da fronteira agrícola. Os agricultores cuidaram de ocupar a fronteira interna dos estabelecimentos com a produção. De 1990 em diante, a conquista de novas áreas tem pequena expressão, em termos da área já ocupada pela agricultura, e mesmo assim é fenômeno mais restrito à Amazônia.

Como resultado das políticas de governo e da ação da iniciativa particular, o agronegócio deslanchou. Tirou vantagens das condições favoráveis da demanda interna e externa para diversificar a pauta de exportações, antes baseada tão somente no café ${ }^{6}$. A agroindústria, muito impulsionada pelo governo e pelo mercado, integrou os campos com as cidades e com o mundo inteiro. O centro de decisões caiu nas mãos dos interesses urbanos e, em certos casos internacionais. A maior parte da produção se guiou por conhecimentos gerados pela ciência. Grande parte dos financiamentos à produção escapou dos bancos oficiais para a iniciativa particular. Nesta integração das cidades com os campos, com dominância da urbis, perdeu sentido a velha divisão das contas nacionais. O processo de produção tem etapas nos campos, nas cidades e no mercado internacional, obviamente com especializações em cada etapa. E aí reside a essência do conceito agronegócio.

\subsection{Agronegócio, agricultura familiar e reforma agrária a partir 1988.}

Nesta fase, o agronegócio e a agricultura familiar tornaram-se dois componentes importantes da política agrícola que passou a ter no desenvolvimento da agricultura e na distribuição de renda nos campos sua preocupação principal. Para formalizar nosso entendimento daquilo que foi uma das ideias importantes, no primeiro governo militar e na discussão da Constituição de 1988 e ainda perdura até os dias que correm, consideraremos as percepções que estavam por traz daquelas ideias:

6 O açúcar foi outro importante produto de exportação, de pequeno vulto se comparado com café. 
a. Terra e trabalho são os dois fatores de produção e equipamentos são produzidos no meio rural, em nível de estabelecimento. O custo destes equipamentos basicamente corresponde ao gasto com trabalho;

b. Trabalho (L) e terra (T) são utilizados em proporção fixa. É como se houvesse um único fator de produção na função de produção. Ou seja,

$$
\frac{T}{L}=\alpha
$$

Para simplificar a linguagem, vamos admitir $\alpha=1$. Ou seja, se para dobrar a área explorada é preciso dobrar o número de trabalhadores e vice-versa. Ainda se o trabalhador cuida de um hectare, a família de seis membros necessitará de seis hectares, outro tanto para pousio e mais a área de reserva ${ }^{7}$;

c. Para dobrar a produção dobra-se a área, ou equivalentemente, o número de trabalhadores. Esta hipótese decorre de que se pode sempre repetir a mesma experiência, se as circunstâncias forem equivalentes. Trata-se de função de produção homogênea de grau 1. Logo,

$$
\begin{gathered}
Y=f(L)=\operatorname{Lf}(1) \quad(1) \\
\frac{Y}{L}=f(1)(2) \\
\frac{d Y}{d L}=f(1)(3) \\
\frac{Y}{L}=\frac{d Y}{d L}
\end{gathered}
$$

7 Não se usa fertilizante. O tamanho ótimo do estabelecimento é indeterminado. 
Ora Y é a produção. E a equação (1) descreve o modelo de produção, sendo que (2) e (3) referem-se, respectivamente, à produtividade média do trabalho e à sua produtividade marginal. No caso pela equação (4), as duas produtividades são iguais e constantes. É fácil ver que elas são iguais a $\mathrm{f}(1)$. Neste modelo, a produtividade da terra corresponde à produtividade total dos fatores, e, por isto, ela foi escolhida como o índice apropriado para as desapropriações para efeitos de reforma agrária. O que foi correto apenas quando a equação (1) descrevia a produção, o que não é correto hoje. Outro ponto importante, o modelo implica na estagnação da produtividade da terra ou em uma tendência de queda, em consequência de lixiviação, erosão, pragas e doenças.

\section{d. Como se reparte a renda?}

Há duas possibilidades:

d1: Organização de produção é familiar, sem trabalho assalariado. A família estabelece a remuneração dos membros. O limite superior é a produtividade média. Se o mercado urbano estiver pagando menos, há opção de pagar o equivalente a este salário. Neste caso, haverá poupança. Se ele paga igual, e a família quiser segurar os seus membros no meio rural, terá que pagar o mesmo salário do meio urbano. Se meio urbano, paga mais que o valor da produtividade média do trabalho, a tentação de migrar é muito grande. Claro que fatores culturais podem retardar o êxodo rural, mas não por muito tempo. Note-se que neste modelo de produção, a remuneração da terra é nula. A família pode reter uma parcela da remuneração para poupança e para fazer face às incertezas. $\mathrm{O}$ limite inferior é o nível de subsistência, abaixo do qual a remuneração não pode cair. Caso contrário, a saída é o êxodo. Como os salários variam pouco, ou equivalentemente a produtividade média e a marginal, a desigualdade de renda é insignificante Daí somente enfatizar-se a distribuição da terra em módulos familiares, na retórica da época;

d2: Organização da produção com trabalho assalariado. O limite de salário é produtividade média, neste caso o aluguel da terra seria zero. O dono da terra não concordaria com isto, obviamente, e vai tentar pagar 
menos, sendo o limite inferior o salário subsistência. O mercado de trabalho urbano pequeno, na presença de elevadas taxas de crescimento da população rural, favorece a convergência para o salário de subsistência. A escravatura levou os escravos para este limite. E a diferença entre este salário e o equivalente à produtividade média fica com o dono da terra e sua família que administram a propriedade. A distribuição de renda daí derivada é muito desigual. Surge a massa de assalariados rurais. A instabilidade social floresce. E num ambiente democrático, deságua em forte pressão por mudanças, e, finalmente, por políticas que deem aos trabalhadores acesso à terra. Chega-se à vez da reforma agrária.

O crescimento das demandas interna e externa levou a oferta responder pela incorporação de mais terra ao processo de produção. Pelo modelo, quando se dobra a área explorada dobra-se a necessidade de trabalhadores. Para se evitar a pressão sobre salários, os escravos foram trazidos da África. Depois vieram os trabalhadores europeus e asiáticos.

Este tipo de organização da produção predominou por séculos no Brasil e junto com ela o estímulo à grande propriedade, que tem origem no Brasil colônia.

\section{e. Como se explica o êxodo rural neste modelo?}

Se a população rural crescer mais que a área agricultável, sem aporte de tecnologia, o salário médio irá decrescer. E um limite ocorrerá em que a opção migrar é considerada e adotada pelos membros da família.

Ou ainda, os salários urbanos se distanciam dos rurais, e o poder de atração das cidades torna-se irresistível. Simultaneamente, os dois fenômenos ocorreram. Com a industrialização, ainda no período da opção pela agricultura tradicional, com o agravante das políticas que discriminaram o meio rural, as luzes das cidades atraíram milhões de migrantes, porque os salários urbanos se distanciaram dos rurais. 


\section{f. A opção pela reforma agrária e pela agricultura familiar}

A reforma agrária já estava na retórica política, na década de cinquenta e mesmo antes. Em 1964, surge o Estatuto da Terra. O argumento era a necessidade de ampliar o mercado interno, aumentando o poder de compra da massa de assalariados rurais, ainda parte expressiva da população brasileira, fazer a produtividade da terra crescer, tirando-a do sua centenária estagnação e abastecer o mercado interno. Deste modo, a ideia era de romper com o modelo de produção acima, traduzido na equação 1. Àquela época, a preocupação com a distribuição de renda era menos importante. Os militares logo esqueceram a reforma agrária, e, neste aspecto, concentraram esforço em assentamento na região Norte, visando marcar presença lá com a agricultura, também apaziguar conflitos e conquistar aliados.

Com a redemocratização, no ambiente da Constituição de 1988, a reforma agrária virou tema dominante em acirrados debates, ficando bem estabelecidos os dois campos, a favor e contra. $\mathrm{O}$ a favor, querendo uma reforma agrária irrestrita, com o objetivo de quebrar o poder originário na grande propriedade. O outro campo, querendo preservar a estrutura de produção e o modo de produção capitalista, fundamentado no modelo de produção:

$$
Y=f(\mathrm{~T}, \mathrm{~L}, \text { Insumos Modernos })(5),
$$

Com a adição de interligar os campos com os mercados urbano e externo e fundamentar a agricultura na ciência. Este era um aspecto comum às visões em conflito. Com o objetivo de quebrar a resistência ao modelo de produção acima e de ampliar o mercado para os produtos industriais, os dois campos entraram em acordo, e as propriedades produtivas, conforme modelo acima, mesmo que escapassem dos limites de tamanho ficaram impedidas de serem desapropriadas. E a reforma agrária foi aprovada, tendo a agricultura familiar sido definida para efeito de políticas públicas. Ressalte-se o papel do INCRA na execução da reforma agrária e a criação de Ministério específico para geri-la e cuidar da agricultura familiar, 
mais recentemente o MDA. As organizações sociais constituem grupos de pressão importantes ${ }^{8}$.

A impossibilidade de desapropriar as propriedades produtivas mudou o rumo da reforma agrária, e ela se concentrou na luta contra os latifúndios. Perdeu-se muito de sua capacidade de mudar a nossa distribuição de terra, a qual pouco se alterou. Mas, não perdeu ela a capacidade de pressionar as grandes propriedades para atingirem níveis de produtividades da terra acima do mínimo exigido, se elas quisessem escapar às desapropriações. Neste aspecto, teve peso importante no desenvolvimento do agronegócio, além de cumprir outros objetivos.

As políticas de estímulo ao agronegócio passaram a conviver lado a lado com aquelas referentes à agricultura familiar e reforma agrária. Neste período, o Brasil se transformou num dos maiores exportadores do mundo. $\mathrm{O}$ agronegócio se consolidou e muito foi feito pela agricultura familiar e reforma agrária.

\section{Fatos relevantes}

Políticas públicas produzem resultados. $\mathrm{Na}$ análise dos mesmos, se procurou realçar aspectos importantes do ponto de vista nacional, tanto no que diz respeito ao agronegócio, à agricultura familiar e à reforma agrária. Separar agricultura familiar do agronegócio é incorreto, quanto a resultados. Um bom exemplo é a cesta básica, em que é difícil separar as contribuições da agricultura familiar ${ }^{9}$ e do agronegócio. As exportações caracterizam um caso diferente. A primeira vista representam um ganho do agronegócio. Ora, se não fosse ter sido bem abastecido o mercado interno, elas não teriam ocorrido. Por isto, se juntou agricultura familiar com o agronegócio, como categoria, e a outra é a reforma agrária, em que

8 O programa que visa erradicar a miséria tem muito a ver com o meio rural. Pertence ao Ministério do Desenvolvimento Social, mas foge ao escopo deste trabalho. Também a aposentadoria rural. Reter população no meio rural constitui um dos objetivos. Mas, atração das cidades tem sido mais forte. Veja Alves, Souza, Rocha e Marra (2013).

9 Definição da lei. 
se destacam os assentamentos realizados. Seus resultados, em termos de produção, estão na primeira categoria.

\subsection{Agronegócio e agricultura familiar}

Destacamos os seguintes aspectos:

a. Interligação estreita com o mercado externo e interno. Exportar é tão crucial à sobrevivência, como abastecer as cidades. $\mathrm{O}$ excedente exportado redundou em importante saldo na balança comercial. Este saldo tem equilibrado nossas contas externas, contribuído para o acúmulo de reservas externas e para aumentar a confiança na economia brasileira.

Afirma-se que as exportações da agricultura constituem involução na direção de bens que não cristalizam conhecimentos e inovações. Ora isto é desconhecer o que é exportado pela agricultura. O peso dos insumos comprados e não agrícolas corresponde a menos $60 \%$ do custo total, em nível de porteira do estabelecimento. Ainda os grãos, as frutas, as flores, produtos florestais e as carnes exportadas concentram vasta gama de conhecimentos e tecnologias apropriadas pelos agricultores e agroindústrias, tanto do lado dos insumos, produtos, transportes, processamento da produção e armazenamento.

\section{b. Cesta básica}

Há um trabalho feito por pesquisadores da Embrapa, no qual se baseia a discussão sobre a cesta básica. Veja (Souza, Alves, Gomes e Marra, 2013).

No que respeita ao preço da cesta básica, há três períodos distintos, a saber:

\section{b1: Crise de abastecimento interno, insegurança nas metrópoles e perda de oportunidades de exportação num mercado internacional de commodities aquecido. Período Janeiro de 1970 a Janeiro de 1976.}


Em setenta e dois meses, de janeiro de 1970 a janeiro de 1976, o preço da cesta básica cresceu ao ano à taxa de $\mathbf{6 , 5 2 \%}$, e no período todo à taxa de $\mathbf{3 9 , 1 3 \%}$.

\section{Efeito}

O governo militar mudou a política agrícola, que era baseada na expansão da fronteira agrícola, para aquela que enfatizava o crescimento da produtividade. Criou a Embrapa e os estados ampliaram os investimentos nos institutos de pesquisa, investiu nos programas de pós-graduado em ciências agrárias, ampliou os investimentos em crédito rural subsidiado, na extensão rural e na construção de estradas, armazéns, agroindústria e na comunicação em geral. Aquelas políticas permanecem até os dias de hoje, variando a ênfase e intensidade.

\section{b2. Queda prolongada dos preços da cesta básica. Período fevereiro de 1976 a agosto de 2006.}

No período de trezentos sessenta e sete meses. De fevereiro de 1976 a agosto de 2006, a taxa anual de queda anual do preço da cesta básica foi de $\mathbf{3 , 1 2 \%}$. No período todo, $\mathbf{9 5 , 5 8 \%}$.

\section{Efeito}

Enorme transferência de renda para os consumidores brasileiros e do mundo todo, em vista do crescimento das exportações. Como os consumidores mais pobres gastam a maior parte do orçamento familiar com a compra de alimentos, eles foram os mais beneficiados, (Barros, 2010). Os ganhos de produtividade da agricultura fundamentaram o crescimento da oferta e, por isto, aumentaram o poder de competição da nossa agricultura, e as exportações avançaram persistentemente (Souza, Alves, Gomes e Marra, 2013). A insatisfação e instabilidade nas capitais, em função dos preços dos alimentos, desapareceram. 


\section{b3. Crescimento acentuado dos preços internacionais das commodities e dos preços do petróleo e recuperação do preço da cesta básica. Período: setembro de 2006 a julho de 2012.}

Em 71 meses, no período, setembro de 2006 a julho de 2012, o preço da cesta básica cresceu à taxa de anual de $\mathbf{2 , 7 3 \%}$ e no período todo à taxa de $\mathbf{1 6 , 1 6 \%}$.

As causas apontadas do lado do incremento da demanda referem-se ao crescimento da renda per capita, da população e, da população, urbana, na Ásia, especialmente da China, e à incapacidade da produção local de atender a esta demanda, com a consequente expansão das importações. Do lado das restrições ao crescimento da oferta, realça-se a crise do petróleo, e seu efeito no custo de transportes, processamento da produção e nos preços de fertilizantes (Brandão, 2013) e a infraestrutura deficiente de transportes e portos.

Os preços internos dos alimentos são críticos. Pesam nas taxas de inflação e no humor das cidades. Ainda afetam muito mais o poder de compra dos mais pobres. E, por estas razões, eles são motivo de preocupação constante do governo. Mas, há sinais de estabilização dos mesmos, porque ao contrário do início da década de 70, conta-se agora com agricultores competentes, tecnologia e política agrícola, visando expandir a produção, nos seus componentes agricultura familiar (Pronaf) e agronegócio. Ainda, se contou com o efeito amortecedor de tensões que o aumento do salário mínimo trouxe.

c. O crescimento da produtividade da terra, ou seja, a tecnologia, explica em grande parte o crescimento da produção. Sem este crescimento, alguns milhões de hectares de florestas teriam que ser devastados para se obter a atual produção. Assim, o desenvolvimento da agricultura procurou poupar recursos naturais (Gasques et al., 2013). Ainda, gerou excedente que abastece o mercado interno e externo, financia as políticas de transferência de renda e desenvolvimento econômico, em geral. 
d. Constatou-se grande concentração da produção conforme mostrado pelos dados do Censo Agropecuário 2006. Ora 11,4\% dos estabelecimentos que relataram produção e ter usada terra para produzir, geraram 87\% do valor da produção. Neste grupo, 27.306 estabelecimentos geraram $51,2 \%$ daquele valor. Ou seja, 53.332 estabelecimentos, do mesmo nível de produção, teriam produzidos toda a produção relatada pelo Censo. Quando se mede a concentração da produção, produto a produto, repetese o mesmo panorama. Veja, Alves, Souza, Rocha e Marra, (2013)

e. A tecnologia é responsável pela concentração. Pelo Censo Agropecuário 2006, os insumos que carregam tecnologia explicaram 68,1\% do crescimento da produção; trabalho $22,3 \%$; e terra $9,6 \%$. Para o valor bruto de produção, mediu-se o índice de Gini para o grupo de estabelecimentos de área igual ou menor que cem hectares e para os de área maior que cem. Os índices resultaram respectivamente iguais a 0,85 e 0,87 . Ou seja, a desigualdade de renda bruta é praticamente a mesma nas duas classes e muito elevada. Observando-se o valor da produção, calcularam-se os índices de Gini para os municípios que tinham dados suficientes a este propósito. Tecnologia, à exceção do Norte e Centro-Oeste, explicou a maior parte da variação do índice de Gini. Observando-se as duas classes acima mencionadas, e em cada um dos 5.036 municípios estudados, foi calculado o índice para cada uma delas. Denominou-se de Gini1 para a área menor ou igual a 100 hectares. E Gini2 para a outra classe $(>100$ ha). Em 3.035 municípios (60,3\%), obteve-se Gini2 $\leq$ Gin1. Mediana respectivamente igual (Gini1 e Gini2) a 0,72 e 0,70; e média 0,73 e 0,70. Sendo assim, o índice de Gini é um pouco maior na classe de menor área. Logo terra não explica a desigualdade da renda bruta. $\mathrm{O}$ estudo mostrou a dominância da tecnologia. Dentro de cada uma das duas classes, é a tecnologia que produziu a desigualdade. Note que se estudou o valor da produção, mais detalhes em Alves, Souza, Rocha, (2013).

f. Pelo Censo de População 2010, 85\% da população brasileira residem nas cidades. No período 1990-2000, o êxodo rural somente explicou 3,5\% do crescimento da população urbana. A população rural concentra-se no Nordeste, 47,8\%. Norte 14,1\%; Sudeste 19,1\%; Sul 13,8\%; e Centro- 
Oeste 5,2\%. Assim, o Nordeste tem mais do dobro da população do Sudeste (2,5 vezes). Pelo Censo Agropecuário 2006, a renda bruta de cada estabelecimento do Sudeste equivaleu a 4,7 vezes à do Nordeste (Alves, Souza e Marra, 2012). Embora, na última década a migração rural tenha contribuído muito pouco para o aumento da população urbana, o Nordeste acumula no meio rural, um potencial respeitável de migrantes de baixa renda. Quanto às demais regiões, como proporção da população total, a do meio rural é pouco expressiva, e por isto, se migrar conforma os padrões do passado, pouco impactará as cidades. O perigo é o Nordeste mudar o seu padrão migratório, acelerando o passo. Isto pesou na decisão do governo federal de ter o Nordeste como prioridade de suas políticas sociais e de investimentos. Na última década, nas regiões Sul e Sudeste, em função da prosperidade de suas cidades e pequeno tamanho da população rural como proporção da população urbana, a intensidade do êxodo rural foi bem maior que a do Nordeste (Alves, Souza, Rocha, Marra, 2013), mas com pouco reflexo na urbanização;

g. Atribui-se preocupante dualidade da agricultura à extensão rural pública, do ponto de vista da insuficiência e qualidade dos extensionistas. É desejável ampliar o tamanho da extensão rural e aprimorar o seu desempenho. Contudo, se não forem removidas as pedras de tropeço que existem fora da porteira dos pequenos produtores, será inútil o esforço com o objetivo de ampliar os investimentos públicos em difusão de tecnologia. Em síntese, estas pedras de tropeço fazem serem bem menores os preços recebidos e bem maiores os dos insumos comprados pela pequena produção, a ponto de tornar não lucrativa a tecnologia que faz cada hectare produzir mais, a qual é indispensável para solucionar o problema de pobreza via agricultura. O que se requer é mais extensão e de melhor qualidade, num ambiente em que a pequena produção tenha igualdade de condições, quando comparada com a grande (Alves, Souza e Rocha, 2013) ${ }^{10}$.

10 Salientem-se o PRONAF e as aquisições pelo governo federal para evitar a queda de preços de produtos, na luta contra as imperfeições de mercado e do crédito rural. 


\subsection{Reforma agrária}

Se o objetivo da reforma agrária fosse o sucesso apenas, as duas regiões alvo teriam sido o Sul e o Sudeste, em vista da experiência que acumularam com a agricultura tecnificada, por disporem de mercados de produtos e insumos dinâmicos, de cooperativas e assistência técnica de melhor qualidade, de rede de agências do Banco do Brasil e dos bancos particulares de grande capilaridade. Enfim, estas duas regiões se adiantaram muito, comparando-se com as outras três, na solução dos problemas de imperfeições dos mercados. E o Sul se destacou mais em relação ao Sudeste neste aspecto.

O Norte e o Centro-Oeste teriam sido rejeitados em vista de serem deficientes nos aspectos mencionados e terem problemas sérios de estradas e de comunicação; o Nordeste pelos problemas de seca, pouca experiência com a agricultura tecnificada, grau de instrução da população rural e imperfeições de mercado. Acresce-se atualmente, no Norte, o tamanho da reserva legal e má vontade com agricultura, de um modo geral.

Contudo, o sucesso fácil não foi o critério de seleção. Quanto ao Norte e Centro-Oeste, pesou na balança a existência de terra barata, de terras da união, de imensos latifúndios, a necessidade de ocupar a região Norte, de levar o governo e assistência técnica a regiões que somente conheciam a agricultura primitiva e extrativa. Também nestas regiões era muito menor a resistência organizada à reforma agrária.

Em vista da produtividade do trabalho na agricultura do Nordeste ser muito baixa, se concluiu pela existência de excesso de população visà-vis a sua capacidade produtiva. Assim criar oportunidades de trabalho nas agriculturas da região Norte e Centro-Oeste, regiões estas vizinhas, via reforma agrária, foi considerado como parte da solução do problema de pobreza rural nordestino. 
Ainda quanto ao Nordeste, perto da metade da população rural brasileira lá residia, população muito pobre comparada com a do Sul e do Sudeste, e com o pé na estrada para migrar. A hipótese dominante era ser a estrutura agrária dual, com grandes propriedades de um lado, pequenas e minifúndios do outro, responsável pela pobreza da região. Assim, a solução agrícola do problema de pobreza dependeria essencialmente de quebrar a estrutura agrária dual em favor de mais igualdade na distribuição da terra. Por essas razões se priorizou o Nordeste. A CODEVASF foi um braço do programa de reforma agrária, no tocante à irrigação, mas braço de pequeno porte ${ }^{11}$.

Os dados da Tabela 1 refletem as escolhas feitas pelo governo. As três regiões citadas concentraram $97,5 \%$ da área ocupada pelos beneficiados e $90,9 \%$ das famílias. Ainda o Nordeste é a segunda região no que respeita a área ocupada e número de famílias beneficiadas. A região Norte se destacou muito tanto quanto à área e quanto às famílias beneficiadas, embora fosse um grande vazio demográfico e muito deficiente em outros aspectos. Quanto à área ocupada em relação a total, ela obteve 76,40\%; quanto às famílias beneficiadas também em relação ao total, chegou a $40,96 \%$. O Nordeste ocupou o segundo lugar, quanto à área beneficiada $12,02 \%$, muito distante da região Norte, e quanto às famílias beneficiadas, $32,59 \%$. A relativa ênfase no Nordeste quanto às famílias beneficiadas, como a Tabela 1 indica, representou decisão correta e preocupação com a região onde se localiza a maior parte da pobreza rural brasileira. Mas, se correu muito risco do ponto de vista de demonstrar resultados para a sociedade, em vista dos inúmeros obstáculos que a região oferece, tanto quanto ao meio físico e população, como quanto aos mercados.

11 A não desapropriação da propriedade produtiva reduziu o poder da reforma agrária de influenciar a distribuição da terra. As desapropriações alcançaram os latifúndios e terras improdutivas. A compra de terra é outra possibilidade. Preservar as propriedades produtivas se mostrou, contudo, acertado. 
Tabela 1: Área, em hectares, e famílias assentadas pelo programa de reforma agrária até dezembro de 2012, regiões e Brasil.

\begin{tabular}{|l|l|l|l|l|l|}
\hline Regiões & Área (ha) & $\%$ & Famílias $\left(\mathrm{n}^{\circ}\right)$ & $\%$ & ha/família \\
\hline Norte & 67.137 .826 & 76,40 & 515.355 & 40,96 & 130,27 \\
\hline Nordeste & 10.563 .324 & 12,02 & 410.092 & 32,59 & 25,76 \\
\hline Centro-Oeste & 7.987 .507 & 9,09 & 217.928 & 17,32 & 36,65 \\
\hline Sudeste & 815.983 & 1,57 & 59.289 & 4,72 & 23,23 \\
\hline Sul & 1.377 .532 & 0,92 & 55.541 & 4,41 & 14,69 \\
\hline Brasil & 87.882 .172 & 100,00 & 1258.205 & 100,00 & 69,85 \\
\hline
\end{tabular}

Fonte: www.incra.gov.br, dados atualizados em 24/07/2013.

As Tabelas 2 e 3 dizem respeito aos financiamentos de custeio e investimento e aos contratos assinados. O custeio corretamente medido, incluindo-se, banco, recursos próprios e crédito de particulares, prediz aproximadamente a próxima safra. Mede, portanto, a pujança do estabelecimento. Os dados se referem à agricultura familiar. No caso da agricultura familiar e dos beneficiários da reforma agrária, o crédito de custeio via Pronaf é aproximação razoável do crédito de custeio total. Já o crédito de investimento diz respeito ao futuro. Seu papel é melhorar a infraestrutura de produção e de moradia. Sendo assim, investimento e custeio têm dimensões temporais diferentes e não faz sentido somálos. Fizemo-lo para indicar a distribuição do montante despendido pelo Pronaf, em 2012.

Viu-se que $97,5 \%$ da área ocupada pelos assentamentos situam-se nas regiões Norte, Nordeste e Centro-Oeste. No caso das famílias beneficiadas, esta porcentagem corresponde a 90,9\%. Também as três regiões, principalmente o Nordeste, concentram parte ponderável das famílias da categoria agricultura familiar. Assim sendo, a tabela 2 deveria apresentar números que guardassem alguma correspondência com os $97,5 \%{ }^{12}$. Muito próximo do oposto ocorreu. Sul e Sudeste concentraram

$12 \mathrm{O}$ Pronaf financia a agricultura familiar e não tão somente aos beneficiados da reforma agrária. Mas o Nordeste concentra parte muito expressiva da agricultura familiar, e 1.258.205 famílias beneficiadas pelo programa tem peso no total de famílias da categoria agricultura familiar, no mínimo $30 \%$. 
$81,24 \%$ dos recursos aplicados em custeio. E somente o Sul, 62,22\%. Teriam as três regiões fracassadas em transformar terra da agricultura familiar em produção? Pela frieza dos números, não há como negar esta afirmação, em vista da elevada correlação entre crédito de custeio e produção. Qual é a causa? Ora as condições de produção do Sul e Sudeste são muito melhores: cooperativas, desenvolvidas, capilaridade bancária e competência dos seus gerentes também desenvolvida, mercados de insumos e produtos com muito menores discriminações contra a pequena produção, assistência técnica particular e pública dinâmica, para não falar em estradas tronco e vicinais, disponibilidade e qualidade da eletricidade, facilidades de exportação, mídia, internet e presença do governo e qualidade da assistência que presta. Fosse o MDA bem abastecido de recursos para a assistência técnica, muito pouco teria mudado nos números, por causa do poder dos obstáculos apontados. $\mathrm{O}$ efeito deles é reduzir a lucratividade das tecnologias que podem redimir os pequenos produtores. Sendo assim, muitos preferiram continuar com o tradicional e não correr riscos. Por isto, as famílias daquelas regiões não tomaram dinheiro emprestado ao Pronaf como o fizeram as do Sul e Sudeste.

Saliente-se que o Nordeste destoa em relação aos valores por contrato para custeio e investimento. O desejo de correr menos risco é uma causa. A outra é a opção pela agricultura tradicional, ou seja, por apegarem-se ao que estavam acostumados. Também há resistência dos bancos e dos técnicos, que é o que se espera em condições de risco e de imperfeições de mercado. Ficar no mesmo é pedra de tropeço no caminho de uma solução agrícola para a pobreza rural ${ }^{13}$ !

13 São os agricultores que decidem tomar empréstimo. Com a falta de lucratividade da tecnologia moderna na presença de imperfeições de mercado, a recusa deles é decisão correta. 
Tabela 2 - Distribuição por região, em \%, dos financiamentos rurais e R\$/contrato do Pronaf, 31/12/2012.

\begin{tabular}{|c|c|c|c|c|c|}
\hline \multirow{2}{*}{ Regiões } & Custeio & Investimento & Total & Custeio & Investimento \\
\cline { 5 - 6 } & $(\%)$ & $(\%)$ & $(\%)$ & $\mathrm{R} \$ /$ contrato & $\mathrm{R} \$ /$ contrato \\
\hline Norte & 2,79 & 10,99 & 7,25 & $13.714,27$ & $14.813,16$ \\
\hline Nordeste & 5,29 & 22,35 & 14,59 & $5.018,20$ & $2.664,68$ \\
\hline Centro-Oeste & 6,32 & 6,46 & 6,40 & $15.834,25$ & $26.582,76$ \\
\hline Sudeste & 20,93 & 22,50 & 21,79 & $12.429,16$ & $14.535,15$ \\
\hline Sul & 64,67 & 37,70 & 49,97 & $11.745,56$ & $17.610,34$ \\
\hline Brasil & 100,00 & 100,00 & 100,00 & $11.303,14$ & $7.655,49$ \\
\hline
\end{tabular}

Fonte: Banco Central, Anuário Estatístico do Crédito Rural (www.bcb.gov.br).

Enfatiza-se ser o crédito de custeio sinal de vitalidade do estabelecimento pela alta correlação que tem com a produção, visto financiar a compra dos insumos. A tabela 3 mostra que a dominância do Sul e Sudeste persistiu em relação aos contratos assinados, 81,26\%. Quanto a contratos de investimentos, a região Nordeste foi dominante. Mas, com valor por contrato muito pequeno, destoante mesmo, e assim se fugiu lá de mudanças mais drásticas na infraestrutura de produção. Preferiu-se apenas reforçar o tradicional.

Tabela 3 - Distribuição por região, em \%, do número de contratos assinados, em 31/12/2012, custeio e investimento.

\begin{tabular}{|l|l|l|l|}
\hline Regiões & Custeio (\%) & $\begin{array}{l}\text { Investimento } \\
(\%)\end{array}$ & $\begin{array}{l}\text { Total } \\
(\%)\end{array}$ \\
\hline Norte & 2,31 & 5,68 & 4,46 \\
\hline Nordeste & 11,92 & 64,22 & 45,34 \\
\hline Centro-Oeste & 4,51 & 1,86 & 2,82 \\
\hline Sudeste & 19,04 & 11,85 & 14,44 \\
\hline Sul & 62,22 & 16,39 & 32,94 \\
\hline Brasil & 100,00 & 100,00 & 100,00 \\
\hline
\end{tabular}

Fonte: Banco Central, Anuário Estatístico do Crédito Rural (www.bcb.gov.br). 
É importante reconhecer o que a reforma agrária fez na ocupação da região Norte e Centro-Oeste pela agricultura familiar, por levar o governo a estas regiões, e, no Brasil todo, por dar oportunidades de acesso à terra a mais de um milhão de famílias. Grupos radicais, desrespeitando as leis, produziram instabilidade nos campos, e ação deles se reflete na mídia, exagerando o que realmente ocorreu. Na realidade, em termos de paz social, existiram ganhos importantes.

$\mathrm{Na}$ agricultura descrita pelo modelo de produção (1), a tradicional, a distribuição da terra e da produção são as mesmas, em vista da vinculação do trabalho à terra. Ou seja, no modelo de produção (1), distribuir terra é distribuir renda.

No modelo de produção (5), trabalho se associa aos insumos modernos, especializando-se, e a terra também é construída, acabando-se tão somente com um único conjunto de insumos, os modernos. Nesta perspectiva do modelo de produção (5), são insumos modernos que explicam completamente a distribuição da produção. Sendo assim, eles explicam a concentração da produção. Para o grupo modernizado, terse-á o modelo (6).

\section{$Y=f($ Insumos Modernos) $(6)$}

No modelo de produção estimado recentemente, considerou-se o Modelo (5), porque o Modelo (1) ainda é muito praticado. Fez-se isto para levar em consideração as duas agriculturas. Como vimos, a terra explicou 9,6\% da produção, trabalho 22,3\%, e tecnologia (insumos modernos) 68,1\%. Detalhes estão em (Souza et. al., 2013). Ainda, 27 mil estabelecimentos produziram $51,1 \%$ da produção de 2006 . E quinhentos mil estabelecimentos geraram $87 \%$ daquela produção. $\mathrm{E}$ 3,9 milhões produziram tão somente $13 \%$. E, neste grupo, 2,9 milhões de estabelecimentos contribuíram apenas com 3,3\% daquele valor de produção, e produção de cada estabelecimento foi de meio salário mínimo por mês e por estabelecimento, salário mínimo de 2006, do valor da produção de 2006. A grande lição que estes dados ensinam é 
que distribuir terras em regiões de mercados tão imperfeitos não guarda correlação com distribuir renda. Para melhorar a distribuição da renda rural a chave é dar igualdade de escolhas, quanto às tecnologias, aos pequenos produtores, o que não tem sido buscado com ênfase necessária.

Ou seja, nas condições brasileiras, distribuir terra tão somente não modifica a distribuição da renda bruta. Como já vimos os agricultores de estabelecimentos de cem ou menos hectares são tão desiguais entre eles como os que exploram estabelecimentos de mais de cem hectares de área.

A agricultura familiar, e em particular as famílias beneficiadas pela reforma agrária, colocam o desafio de modernizar a agricultura que praticam. Com insumos modernos ou outra opção. Enfim, necessitam de ter cada hectare produzindo no nível da agricultura do modelo (6). Caso contrário, persistirá a dualidade descrita acima, em que 11,4\% dos estabelecimentos em 2006 produziram $87 \%$ da produção total. E ainda corre-se o risco, em vista da pequena renda comparada com as opções urbanas, de um êxodo rural muito acima das taxas observadas. E para obstá-lo, o Tesouro teria que desembolsar somas bem mais avultadas que as atuais, em políticas de transferência de renda.

O desempenho da agricultura familiar da região Sul, em comparação com as demais regiões, constitui prova empírica de que as imperfeições de mercado são o maior obstáculo à redenção da agricultura familiar. Removê-las é tarefa que se impõe ou não haverá esperança.

As imperfeições de mercado se infiltram na extensão rural, nos regulamentos do crédito rural, na eletricidade rural, nas estradas vicinais, na escola rural, nos oligopólios e oligopsônios, nas normas sanitárias, no código florestal, nos arranjos de mercado que desfavorecem ou discriminam a pequena produção, nas exportações, na aposentadoria rural, no acesso à saúde e à justiça, nos contratos e nas cooperativas, para dar alguns exemplos. 


\section{A Embrapa}

Três tópicos serão abordados: breve história e concepção, impacto na política agrícola e resultados. Mais detalhes em (Martha, Contini e Alves, 2012)

\subsection{Breve história e concepção}

O Instituto Agronômico de Campinas é o precursor da pesquisa agrícola no Brasil. Criado em 1887 é referência nacional e internacional. No nível nacional, influenciou a criação de alguns institutos de pesquisa regionais e de uma coordenação nacional, o Departamento Nacional de Pesquisa Agropecuária (DNPEA). Estes institutos regionais e o DNPEA foram as sementes que deram origem à Embrapa. Não se conseguiu, contudo, fazer o incremento da produtividade da agricultura a prioridade principal da política agrícola nacional.

Em dezembro de 1972, os investimentos do governo federal no DNPEA atingiram, em dólares, 19 milhões de dólares. Pelo IPA americano, equivaleram a 93 milhões, em dezembro de 2012. Pelo CPI, 103 milhões. O orçamento da empresa para 2013 equivale a 1,207 bilhões de dólares. O gasto do governo em 1974 em relação ao PIB da agricultura equivaleu a 0,09\%. Em 2012, os dispêndios na Embrapa equivaleram a mais de $1,0 \%$ do PIB da agricultura. Em relação ao PIB de 1972, os dispêndios atuais do governo cresceram muito, em torno de 11 vezes.

Não obstante a especificidade local, os resultados de pesquisas obtidos em São Paulo se espalharam no Sudeste, Sul e no Centro-Oeste sem impacto na produtividade da terra, em vista de ser a maioria da nossa agricultura tradicional. À época da criação da Embrapa, em 1973, os estados do Rio Grande do Sul, Pernambuco e Minas Gerais já investiam em pesquisa agrícola, numa dimensão bem menor que São Paulo. 
Como já se acentuou a Embrapa nasceu como produto da crise de abastecimento do começo da década de 70. Elevados preços internacionais de alimentos, necessidade de exportar mais e a rápida urbanização geraram forte pressão de demanda que não poderia ser atendida pela agricultura vigente. Deste modo surge a Embrapa como uma instância de inovação institucional que tinha como características principais um modelo de organização de empresa de utilidade pública com escala de operação no nível nacional, descentralização do seu espaço de atuação e unidades de pesquisa especializadas, focadas em resultados. Teve por visão uma agricultura baseada em ciência e tecnologia. Esta foi a principal orientação para a solução do problema de desabastecimento. $\mathrm{O}$ princípio operacional da empresa deste modo, desde sua criação, sempre foi orientado para resultados.

O apoio do governo federal foi crítico à sobrevivência da Embrapa. Desde cedo, entendeu-se a importância da tecnologia para o desenvolvimento de agricultura e o potencial lucrativo para a sociedade e para o governo de uma instituição como a Embrapa. É neste contexto de prioridade governamental que ocorre o esforço para a obtenção de recursos (orçamento) tanto na esfera do executivo como na do legislativo.

Nos primeiros doze anos de sua existência a Embrapa representava uma instituição concebida de modo ousado e moderno, mas em última análise não passava ainda de uma promessa. Durante esses doze anos iniciais foram feitos investimentos enormes no treinamento de recursos humanos e em infraestrutura - aproximadamente seis bilhões de dólares em valores de 2008. O governo federal pagou por este investimento com base apenas na promessa do que a Embrapa poderia representar para a modernização da agricultura brasileira. É importante ressaltar que sem esse apoio do governo federal a Embrapa não teria sido viável.

Ciente dos altos custos envolvidos no esforço do governo para modernizar a agricultura, a administração da Embrapa sempre esteve atenta do risco para a empresa que a falta de realizações poderia representar. Deste modo orientou seus centros de pesquisa para um portfólio de programas 
e projetos com metas de curto prazo e para a conclusão de investigações já em andamento. Além disso, deu atenção especial à disseminação dos resultados existentes. E neste contexto, a mídia teve papel fundamental. Foi em muito responsável pela criação da imagem que a Embrapa tem hoje. É claro que a mídia opera com base em realizações e também em promessas consistentes, desde que essas não demorem por demais a se efetuar. Nos anos iniciais da empresa a mídia deu o suporte fundamental na presença de mais promessas e poucos resultados. Este apoio foi crucial na criação de uma imagem favorável na sociedade e no governo. Deste modo, registre-se a importância que teve a relação competente da Embrapa com a imprensa para o sucesso da empresa. Esta relação competente ajudou o governo a justificar o grande investimento num período de realizações magras.

É surpreendente que ao longo de um período de desequilíbrios macroeconômicos e de políticas não ortodoxas não tenha faltado aportes governamentais ao orçamento da Embrapa. Mesmo quando era somente uma promessa seu orçamento cresceu linearmente até 1982. A partir de 1982 a corporação deixa de ser uma promessa e suas realizações de sucesso passarão a motivar os investimentos continuados do governo.

Souza e Alves (2011) em sua discussão da criação da Embrapa relatam que era pensamento de muitos a criação de uma empresa pequena com a função apenas de coordenação de um programa de pesquisa que, na realidade, seria executado pelas universidades e pelos institutos de pesquisa existentes no país. A opção foi rejeitada, pois logo se percebeu que o sucesso de um programa de pesquisa que servisse de alavanca propulsora da modernização da agricultura em um país de dimensão continental como o Brasil deveria se vascularizar por todo o país. Entendeu-se também que o programa dependeria crucialmente de uma massa crítica de pesquisadores talentosos e com especializações diversificadas. Assim a Embrapa deveria ter escala de operação em todo o território, possuir sua rede de pesquisa própria e ser responsável direta pelos resultados da pesquisa que executava. Este modelo acabou por permitir a nova empresa procurar parcerias e cooperações, nos níveis 
doméstico e internacional, com o setor privado, universidades e institutos de pesquisa. Sendo suficientemente grande, diversa e descentralizada a nova instituição teve condições de representar o governo federal na área agrícola. É dentro dessa lógica que a empresa recebe prioridade do governo na alocação orçamentária e no desenvolvimento institucional.

Souza e Alves (2011) também apontam como principal fator do sucesso e desenvolvimento da Embrapa a sua política de recursos humanos. É de seu capital humano que a empresa deriva seu sucesso. A nova instituição partiu para a formação de um conjunto de especialistas gerando com isto um programa de especialização agressivo que, em seu início, agregou nos primeiros doze anos, cerca de 1.500 profissionais em cursos de mestrado e doutorado no país e no exterior. O seu plano de carreiras oferece salários adequados, e planos de saúde cofinanciados e aposentadoria também cofinanciada. A gestão de pessoal tem como ponto central o incentivo à progressão e ao desenvolvimento humano por meio do oferecimento sistemático de oportunidades de capacitação contínua.

Outros fatores também considerados importantes para o sucesso da Embrapa foram definidos pela integração de seus programas de pesquisa com as tendências internacionais da pesquisa agrícola, exposição ampla à mídia e resultados de pesquisa com muito impacto na sociedade brasileira, tais como o desenvolvimento da agricultura moderna na região de cerrados, fixação do nitrogênio no solo ao ponto de $100 \%$ das necessidades da planta no caso da soja e a geração de tecnologias redutoras do uso de agrotóxico e da erosão do solo.

$\mathrm{Na}$ área internacional, a Embrapa mantém laboratórios virtuais -Labex - sem infraestrutura física, em convênios com outros países. Por este procedimento, coloca técnicos seniores para trabalhar com pesquisadores renomados em projeto de interesse comum aos dois países conveniados. Também a Embrapa pode receber pesquisadores do país conveniado, nas mesmas condições. Há Labex nos Estados Unidos (USDA), a primeira experiência, França, Inglaterra, Holanda, Coreia e China. O objetivo é ligar mais estreita e permanentemente os pesquisadores seniores da 
Embrapa com as contrapartes externas, em torno de problemas comuns. Aqui a relação professor-aluno, típica dos programas de pós-graduação e pós-doutoramento, desaparece em favor da interação que existe entre pesquisadores experientes. Mais detalhes em Agropolis, (2013).

É muito intensa a demanda de cooperação externa dos países em desenvolvimento da África, Américas e Ásia, e, neste aspecto, a Embrapa é um instrumento da política externa do Brasil, no que se refere à Agricultura. A fim de atender esta demanda externa, o Congresso Nacional teve que ajustar a legislação que governava a Embrapa, estendendo seu mandato ao exterior.

Outro braço importante é sua relação com a pesquisa particular que é regida por contratos e convênios em tópicos de interesse comum.

Ressalte-se a cooperação com as Universidades - cooperação de dois tipos. Num caso a Universidade e a Embrapa partilham a mesma base física, mas cada qual com suas instalações. Dois exemplos são a Universidade Federal de Pelotas, em Pelotas Rio Grande do Sul, e o Km 47, no estado de Rio de janeiro. No outro, relação entre ambas vararia do informal ao formal, sempre em função de um problema ou problemas importantes no âmbito científico e da sociedade brasileira.

Entre convênios e contratos com as universidades, acumularam-se, até agosto de 2013, 1.059, que abrangem mestrado, doutorado e pósdoutorado e também curso superior. Eles atenderam, a um tempo só, interesses das universidades e da Embrapa, e os recursos são partilhados.

A Embrapa recebe, em suas unidades de pesquisa, estagiários, estudantes e bolsistas no nível médio, graduação, especialização, doutorado e pósdoutorado. No ano de 2012, a Tabela 4 mostra que 2.940 estudantes participaram do treinamento nas diversas categorias oferecidas. 
Tabela 4 Distribuição dos estagiários de universidades na Embrapa, em dezembro de 2012.

\begin{tabular}{|c|c|}
\hline Tipos & $\mathrm{N}^{\mathbf{0}}$ \\
\hline Nível médio & 261 \\
\hline Graduação & 1909 \\
\hline Especialização & 16 \\
\hline Mestrado & 337 \\
\hline Doutorado & 288 \\
\hline Pós-doutorado & 129 \\
\hline Total & 2.940 \\
\hline
\end{tabular}

Fonte: Jefferson Luís da Silva Costa ${ }^{14}$.

É muito forte a interação com o Congresso Nacional, no dia-a-dia, nas audiências públicas e em temas que arregimentam o Congresso, de grande interesse da opinião pública, como foi o Código Florestal.

Como parte do Mapa, a Embrapa é seu braço na área de ciências agrárias. Ela ainda mantém relacionamento estreito com o MDA, MEC e MCTI, que têm muito a ver com seu trabalho, e convênios com outros ministérios, em áreas específicas. Em síntese, ela é um dos braços do executivo em ciências agrárias, e é muito demandada.

\subsection{Impacto na política agrícola}

Distinguiremos os seguintes aspectos sem se aprofundar muito.

a. Prioridade em ciências agrárias.

Esta batalha, em 1973 à época da criação da Embrapa, já estava em curso sob a batuta da extensão rural. E a Embrapa, se incorporou a ela. A criação e o investimento na Embrapa durante 12 anos, ainda com poucos

14 Jefferson Luís da Silva Costa é assessor da Diretoria de Pesquisa e Desenvolvimento da Embrapa. 
resultados, já foi sinal de mudança de atitude em nível do governo federal. Mas, restava conquistar a opinião pública, as lideranças e o agronegócio. Os resultados obtidos, em termos de tecnologias geradas, tornaram esta conquista uma realidade.

Sabiamente não se colocou duas opções como antagônicas, a de expandir a fronteira agrícola ou investir em ciências agrárias. Pelo contrário, enfatizou-se a expansão da fronteira agrícola com tecnologia.

Como exemplos de sucesso, mencionam-se a conquista dos cerrados, áreas da região Norte, o semiárido, com irrigação, grãos nos microclimas favorecidos do Nordeste e agronegócio, em geral. Com o advento da questão ambiental, derrubar mato passou a ser criminoso, e a opinião pública abraçou a causa. Ainda o código florestal, terras indígenas e quilombolas restringiram severamente a oferta de terras à agricultura. O mesmo ocorreu com oferta de trabalho, em vista da queda dramática da natalidade, legislação trabalhista e competição das luzes das cidades. Naquele contexto, a saída para abastecer o país e atender a demanda crescente das exportações ficou patente ser o desenvolvimento tecnológico. E, assim, ciências agrárias, e as tecnologias daí derivadas, passaram a dominar a concepção, formulação e execução da política agrícola brasileira. Ou seja, foram elas reconhecidas como indispensáveis para tomada de decisão nos níveis federal, estadual e municipal e pela sociedade. Como consequência, mudou-se o rumo da política agrícola, optando-se pela modernização da agricultura.

\section{b. Pobreza rural}

Como se salientou, a nossa agricultura é dual. Afluência para 11,4\% dos estabelecimentos e 88,6\% marginalizados da modernização, como estudos publicados pela Embrapa, em livro editado por Alves, Souza e Eliane (2013), demonstraram. A argumentação do texto acima realçou o peso das imperfeições do mercado. Ficou claro que distribuir terra perdeu importância na luta contra as desigualdades de renda no meio rural. Ainda que a solução do problema de pobreza rural necessita de políticas 
de transferência de renda. Ou seja, a solução do problema de pobreza rural pela agricultura é um problema de geração, difusão de tecnologia e de eliminação das restrições de mercado. O acesso à terra, continua importante, desde que aliado ao acesso à tecnologia. Esta compreensão redundou na decisão do governo federal de criar uma Agência Nacional de Extensão Rural e Assistência Técnica (ANATER), em discussão no Congresso Nacional.

\section{c. Área internacional e a Embrapa.}

Ao tempo da guerra fria, os países desenvolvidos, liderados pelos Estados Unidos, estavam muito preocupados com a pobreza rural, e identificaram o atraso tecnológico como a principal causa. Na década de 70, o Brasil resolveu enfrentar o desafio, dentro da visão de construção de instituição (institutional building). Nasceu a Embrapa e os investimentos em ciências agrárias nas nossas universidades escalonaram-se. A cooperação internacional passou a ser guiada pelo princípio da parceria voltada à construção de instituição e à solução de problemas específicos. Sem a dominância externa, portanto.

Compreendeu-se que sem recursos humanos de nível de qualidade internacional nossa pesquisa nunca iria deslanchar. Na Embrapa e nas universidades, desenvolveu-se amplo programa de treinamento em nível de doutorado e de mestrado. A cooperação externa de universidades, de governos, de bancos com o BID e BIRD, e do CGIAR ajudou muito o Brasil. Hoje conta-se com base de recursos humanos e abertura externa que deu-nos credibilidade internacional e capacidade de enfrentar as dificuldades da nossa agricultura. Ainda desenvolveram-se os Labexes que envolvem cooperação externa, em nível do governo.

Para problemas específicos, quando necessário, buscou-se a ajuda de especialistas ou de instituições específicas. E assim tem sido com a grande ajuda dos Labexes. 
Para problemas complexos, buscaram-se países. O caso mais famoso diz respeito aos cerrados. No início, procurou-se a Universidade da Carolina do Norte, na base de um professor e de pequena equipe. Depois se procurou no governo Japonês, recursos financeiros, de técnicos, financiamento para os agricultores e investimentos em infraestrutura de pesquisa e no programa de pós-graduação.

A França trouxe equipe especializada, recebeu brasileiros para treinamento em nível de doutorado e juntou sua experiência na África à brasileira para entender os cerrados e desenvolver tecnologia. O CIMMIT se juntou à Embrapa nos programas de pesquisa em trigo e milho, e o CIAT em feijão e pastagens. Mais detalhes, (Alves, 2010).

\section{d. África e países em desenvolvimento}

No mundo em desenvolvimento, à vista do sucesso brasileiro, firmou-se a visão de que tecnologia é caminho para colocar a agricultura a serviço do desenvolvimento do país e de si mesmo. No fundo querem os atalhos fáceis, principalmente pela cópia de tecnologia e importação de mega empresários do agronegócio. Esta visão fracassou no mundo inteiro. Dizse serem nossos solos e climas semelhantes. Solos e climas não plantam, cultivam ou colhem. Quem faz isto são os humanos. Estes deveriam ser comparados com os brasileiros. Que imensas diferenças!

A ciência que desenvolveu nosso agronegócio veio dos Estados Unidos, na maior parte, da Europa e do Japão. Que imensas diferenças de solos, climas e de gente! Aqui foi abrigada em instituições apoiadas pelo governo, assentada em recursos humanos bem pagos, treinados, em base organizacional adaptada ao país e posta a serviço de nossa agricultura e de nossa sociedade. Em suma, com foco em problemas bem definidos. Tudo isto - gente, recursos financeiros, apoio do governo e instituições- é o caminho. Atalhos servem para jogar dinheiro pelo ralo! Reafirma-se que recursos humanos, a instituição que os abrigam e desenvolvem andam juntos. Ejuntos desenvolvem tecnologia! Um sem o outro nada significa! 
A demanda do mundo em desenvolvimento bateu às portas do governo brasileiro e foi bem acolhida. Por enquanto, o modelo equivale a "pediulevou", numa visão de pequenas ações. Aceitam-se as instituições de pesquisa como são. Em Angola, se experimentou algo diferente, com avanços e recuos, sem desfecho previsível. Assim também é nos demais continentes, onde se tem envolvido a Embrapa, respeitando-se integralmente a demanda do país. No Brasil, isto não redundou em nada!

\section{e. Iniciativa particular}

As leis de patentes e proteção aos direitos dos inventores estabeleceram condições para que a iniciativa particular se firmasse definitivamente com braço importante da pesquisa agrícola brasileiro, em pesquisa aplicada. O impacto logo se fez sentir no mercado de sementes, em milho, soja e algodão, e as multinacionais já dominam as vendas nestes mercados, embora em escala bem menor, a Embrapa tem presença nestes mercados, o suficiente para cumprir sua função de regulação, que nunca deve perder.

As áreas não patenteáveis na agricultura são amplas, e é papel da Embrapa se manter ativas nas mesmas.

Quanto às patenteáveis cabe à Embrapa os seguintes papeis: o de produtor de insumos para a iniciativa particular, como genes portadores de propriedades especiais; o de se associar à iniciativa particular, quando de interesse mútuo; o de realizar pesquisas em temas que fujam ao interesse da pesquisa particular, por envolverem riscos elevados, demandarem muitos anos de pesquisa ou corresponderem a mercados de pequena dimensão; quando o tema importante conflitar com outro para o qual já exista tecnologia lucrativa, como, por exemplo, o desenvolvimento de cultivar que reduza substancialmente a venda de um agrotóxico, e esta venda tem mercado lucrativo; e em áreas nas quais é muito complicado guardar segredos, embora patenteável.

É lucrativo para a iniciativa particular e a Embrapa se associarem. Mas, a iniciativa particular prefere se associar com instituições públicas que satisfaçam às seguintes condições: de grande porte e respeitabilidade; 
tradição de assinar e honrar contratos; flexibilidade em administrar o orçamento e pessoal; desburocratizada; corpo técnico capaz, experiente, sério e forte em ciências básicas; ainda, em áreas em que é fácil guardar segredos, dividir tarefas e repartir lucros; e em problemas em que a pesquisa pública tenha laboratórios e competência que lhe dão vantagem comparativa.

Os contratos e convênios compreendem empresas das áreas internacional e nacional, pesquisa, desenvolvimento e transferência de tecnologia, empresas brasileiras e multinacionais. Num levantamento preliminar, nos últimos cinco anos, cerca de 100 contratos foram assinados em cada ano.

\subsection{Resultados em tecnologias geradas}

No que respeita ao passado mais distante, cabe ressaltar as tecnologias que foram fundamentais ao desenvolvimento dos cerrados, a fixação biológica de nitrogênio na soja e algumas gramíneas, cultivares de soja de ciclo longo e curto, adaptação da soja às baixas latitudes, cultivares como bracearias, mombaça, piatã e tanzânia, cultivares de hortaliças, entre estes, os com teor mais elevado de provitamina A, integração lavoura pecuária, combate integrado de pragas e doenças, o gene de resistência à intolerância ao alumínio no caso do milho, cultivares de elevada produtividade para o arroz irrigado e de sequeiro, cultivares de trigo de alta produtividade, cultivo mínimo, teste de progênie para gado de corte e de leite, o sistema mestiço a pasto para gado de leite, feijão resistente ao mosaico dourado, etc.

Cada ano a Embrapa estima a taxa de retorno aos recursos que ela investe, e os resultados estão na publicação de título Balanço Social. Aliás, a empresa sempre procurou ser transparente à sociedade, prestando conta daquilo que nela foi investido. Em 2012, as tecnologias que surgiram naquele ano, foram classificadas em: mais produtividade (52 tecnologias), menor custo (34 tecnologias), mais valor - adicionou valor a produto (19), mais produção em novas áreas (11 tecnologias), 
cultivares de Embrapa e parceiros ( 10 tecnologias) e protege o meio ambiente (26 tecnologias) e geração de empregos (23 tecnologias). No cômputo geral, 70.539 novos empregos foram criados e cada real aplicado gerou R\$ 7,80. Mais detalhes em Balanço Social (2012).

\section{Conclusões}

O texto procurou a analisar as etapas da política agrícola. Mostrou que houve duas opções de políticas, quais sejam a de fazer a oferta de produtos de a agricultura crescer, via margem extensiva, e via crescimento da produtividade da terra e todos os fatores de produção. As ciências agrárias e, em especial a Embrapa, se beneficiaram muito daquela mudança de visão, e muito contribuíram para torná-la aceita por toda a sociedade, associando-se inteligentemente à mídia.

Ressalta a importância das universidades e dos programas de pósgraduação para dotar o Brasil de recursos humanos aptos a enfrentarem os desafios da agricultura. Mostra como importante foi para o Brasil se associar ao mundo desenvolvido, no campo das ciências agrárias, antes numa relação de dependência, agora de igual para igual. O desfio de hoje é como o Brasil pode atender à demanda externa por ciência e tecnologia.

As novas leis de patentes fizeram com que a pesquisa da iniciativa particular crescesse no Brasil, tornasse muito importante e ocupasse espaço antes ocupado pela pesquisa pública. Isto foi grande ganho. Injetou competição no sistema e deu novos parâmetros e opções para a pesquisa pública. Competir, complementar um ao outro, juntar esforços e separar campos, baseando-se em vantagens comparativas, é o que tem que sido feito. Além da competência específica, a pesquisa pública terá que se exceder em flexibilidade, em elaborar, executar contratos e honrá-los.

Quarenta anos de desenvolvimento tecnológico ímpar na história das ciências agrárias. Como resultados, um agronegócio pujante, uma nova economia, a compreensão da capacidade do desenvolvimento 
tecnológico de produzir e agravar desigualdades, de ele ser sócio no desenvolvimento econômico do país, e de ajudar a entender e solucionar os problemas daqueles que ficaram à margem da agricultura moderna. O desafio do agora é transformar o entendimento em propostas e estas políticas públicas.

\section{Referências}

ALVES, E.; MARRA, R. A persistente migração rural-urbana. Revista de Política Agrícola, Brasília, DF, ano 18, n. 4, p. 5-17, out./dez. 2009.

ALVES, E.; SOUZA, G. S.; ROCHA, D. P. Desigualdade nos campos na ótica do censo agropecuário 2006. Revista de Política Agrícola, Brasília, DF, ano 22, n. 2, p. 67-75, abr./jun. 2013.

ALVES, E. R. A.; SOUZA, G. S.; ROCHA, D. P.; MARRA, R. Fatos marcantes da agricultura brasileira. In: ALVES, E. R. A.; SOUZA, G. da S.; GOMES, E. G. (Org.). Contribuições da Embrapa para o desenvolvimento da agricultura no Brasil. Brasília, DF: Embrapa, 2013. p. 49-86.

BRANDÃO, A. S.; ALVES, E. Commodities agrícolas e preço do petróleo. Revista de Política Agrícola, Brasília, DF, ano 22, n. 1, p. 43-54, jan./mar. 2013.

BRANDÃO, A. S. Política agrícola em países de renda média: uma perspectiva brasileira. Revista de Política Agrícola, Brasília, DF, ano 22, n. 2, p. 48-53, abr./jun. 2013.

BARROS, G. S. Política agrícola no Brasil: subsídios e investimentos. In: GASQUES, J. G.; VIEIRA FILHO, J. E. R.; ZANDER, N. (Org.). Agricultura brasileira: desempenho, desafios e perspectivas. Brasília, DF: Ipea, 2010. p. 236-258. 
GASQUES, J. P.; BASTOS, E. T.; VALDES, C.; BACCHI, M. R. P. Produtividade e crescimento: algumas comparações. In: ALVES, E. R. A.; SOUZA, G. da S.; GOMES, E. G. (Org.). Contribuições da Embrapa para o desenvolvimento da agricultura no Brasil. Brasília, DF: Embrapa, 2013. p. 86-94.

SOUZA, G. S.; ALVES, E. R. A. Scientific computing in the context of a successful agricultural research institution. In: PRADO, H. A.; BARRETO, A. J.; CHAIB FILHO, H. (Org.). Computational methods for agricultural research, advances and applications. Hershey: Information Science Reference, 2011. p. 1-5.

SOUZA, G. S.; ALVES, E. R. A.; GOMES, E. G.; MAGALHÃES, E.; ROCHA, D. P. Um modelo de produção para a agricultura brasileira e a importância da pesquisa da Embrapa. In: ALVES, E. R. A.; SOUZA, G. da S.; GOMES, E. G. (Org.). Contribuições da Embrapa para o desenvolvimento da agricultura no Brasil. Brasília, DF: Embrapa, 2013. p. 49-86.

SOUZA, G. S.; ALVES, E. R. A.; GOMES, E. T.; MARRA, R. Pesquisa agropecuária e preços da alimentação básica: uma abordagem alternativa para a avaliação do efeito do investimento em pesquisa agropecuária na mitigação da pobreza no Brasil. In: ALVES, E. R. A.; SOUZA, G. da S.; GOMES, E. G. (Org.). Contribuições da Embrapa para o desenvolvimento da agricultura no Brasil. Brasília, DF: Embrapa, 2013. p. 154-170. 
REVISTA DE ECONOMIA E AGRONEGÓCIO, VOL.11, $N^{\circ} 1$ 